J. Asiat. Soc. Bangladesh, Sci. 40(2): 219-229, December 2014

\title{
USAGE OF ICT FOR SCIENCE EDUCATION IN SOME RENOWNED BANGLA MEDIUM SCHOOL OF DHAKA CITY
}

\author{
MD. MOKTAR HOSSAIN AND FARZANA AHMED MOHUYA ${ }^{\prime}$ \\ Department of Geography and Environment, University of Dhaka, \\ Dhaka 1000, Bangladesh
}

\begin{abstract}
The present research explored the application of Information and Communication Technology (ICT) in Science Education at some selected renowned Bangla Medium Schools of Dhaka City Corporation Area. The study revealed that the main obstacles of practicing ICT in Science Education in these schools are insufficient number of science teachers and computers. Besides, lack of skilled lab teachers or trainers is also a constraint for practicing ICT. Albeit, there are multimedia facilities in most of the selected schools but currently only the RAJUK Uttara Model College of Dhaka Metropolitan Area uses this system properly. However, in recent times, only the students of eight renowned schools of the study area can access the E-book (science textbooks) facility system from different government websites but unable to utilize the service properly due to inadequate and slow internet support system.
\end{abstract}

Key words: Information and communication technology, ICT in science education, Bangla medium school, Dhaka city

\section{Introduction}

Education is one of the main keys to economic development and improvements in human welfare. As global competition grows sharper, education becomes an important source of competitive advantage and appears to be one of the key determinants of standardization of life. However, Science Education is the most important part of an Education System. In today's technology based society application of ICT in the education system is very important. However, computer technology was introduced in Bangladesh during the decades of $1960 \mathrm{~s}$. The computer technology, particularly, ICT entered in the education sector of Bangladesh during 1990s. The facilities of ICT are still not available for all but different academic institutes and research organizations (both in government and private sectors) are trying their best to set up ICT facilities from national to local level in the country. It is also used in the Science Education purposes. Nowadays the Government of Bangladesh $(\mathrm{GoB})$ has undertaken some steps to develop the ICT sector in a systematic way. For this purpose the GoB has launched some facilities, such as, E-book (through different websites, e.g. - http://www.ebook.gov.bd, http://www.nctb.gov.bd, etc.), Digital Class System by introducing Multimedia Classroom (MMC) System, provides one laptop with internet connections, etc. These facilities are provided to various primary and

\footnotetext{
${ }^{1}$ Corresponding author: Email: farzana@du.ac.bd
} 
secondary schools of Bangladesh from 2012 through the government's Access to Information (A2I) Programme.

ICT has a relatively short history in the educational system, but its history and current status are important to understand how they influence teaching and learning. From the first introduction of ICT in schools, the view of ICT has swayed between unlimited faiths in technology as a vehicle for revolutionizing learning, to skepticism about the promises of such developments (Säljö 1999). Schofield (1995), argues that in contrast to earlier technological innovations like TV and video, ICT has some important features that may have a major impact on schools; such as, ICT is interactive and can be used to accomplish extremely varied purposes, from editing text to providing simulations of critical or expensive laboratory equipment, to putting students in direct contact with others from around the world.

Computers and ICT in the Education System of Bangladesh: The Government of the people's republic of Bangladesh has taken an effort to harness the power of ICT formulated its National ICT Policy during the year 2002. A revised National ICT Policy was passed in the parliament in 2009. The National ICT Policy 2009 has incorporated all the components of the National ICT Policy 2002 in a more structured manner. Some of the most important specific policy statements relevant to education are- i) assess skills of ICT professionals and meet gaps with targeted training programmes to overcome the short-term skills shortage in the ICT industry, ii) adopt continuing education and professional skills assessment and enhancement programmes, iii) establish an ICT Centre of Excellence with necessary long-term funding to teach and conduct research in advanced ICTs, iv) promote distance education, v) enhance the quality and reach of education at all levels with a special focus on Mathematics, Science and English, vi) set up institutes and infrastructure for e-learning training programmes and vii) create an eEducation Cell for coordinating and mainstreaming ICT's in education system, etc.

The use of ICT has the potential to enhance the real world experiences, the educational institutions should emphasize on the use of ICT for both administrative and academic efficiency. However, this investigation was undertaken to study the implication of ICT while teaching science related subjects as well as the teaching techniques by applying ICT and also the constraints behind practicing ICT in some educational institutions particularly some reputed primary and secondary level Bangla Medium Schools of Dhaka City Corporation (DCC) Area.

\section{Materials and Methods}

Study Area: The present study was conducted in some selected twelve renowned Bangla Medium Schools of both the Dhaka North City Corporation (DNCC) and Dhaka South City Corporation (DSCC) of the Dhaka City Corporation (DCC) Area, during June to August 2012. While selecting the schools, the present research had given priorities to 
these twelve schools mainly for their academic performances, i.e. excellence in result in the Junior School Certificate (JSC) and Secondary School Certificate (SSC) examinations and other educational facilities like, proper education services, infrastructure facilities, etc. and also the participation of the students in various Extra Curricular Activities (ECA), e.g. participation in science, debate and sports competitions, etc. Besides, the study also considered the geographic location of the surveyed schools which were situated in the North, North-west and South-west part of the City. However, the study area covered some particular zone and ward number of the DNCC and DSCC area (Table 1). Due to time constrains and some administrative difficulties it was not possible to collect information from some of the reputed schools of the North-east, South and South-east part of DCC area.

Primary and Secondary Data Collection: Primary data of different Bangla Medium Schools of DCC area were collected through an effective questionnaire emphasized on ICT in Science Education perspectives. Hence, the primary data were collected through different research methods, such as- FGD (Focus Group Discussion) with Principals and Teachers and questionnaire with the students of the respective Bangla Medium Schools of Dhaka City. On the other hand, secondary data were collected from different journals, research articles and also from different internet sources. However, the major outcome of the questionnaire is discussed in detail in the findings and discussion part of this article. Besides, the location map of the surveyed schools has been produced through GIS (Geographic Information System) technology (ArcGIS, Version- 9.3 software) (Fig. 1).

\section{Results and Discussion}

Brief Statistics about the selected renowned Bangla Medium Schools of Dhaka City Corporation (DCC) Area is presented in Table 1.

From the present research it is observed that though in all the selected schools, Computer Science is included in the syllabus but it is not compulsory, it is an optional subject. However, from Fig. 2 it is found that among the selected schools, the highest number of computers ( 45 computers) was used in the lab of the Dhaka Residential Model College (DRMC). Then the next highest number of computers ( 40 computers) used in both Ideal School and College Motijheel (ISCM) and RAJUK Uttara Model College (RUMC). Alternatively, the lowest numbers of computers ( 20 computers) has been provided to the students of Government Laboratory High School (GLHS) which is not enough for its 2500 students. It is also a bad indicator for practicing ICT in such a reputed school like Government Laboratory High School of Dhaka City. Hence, lack of funding mainly becomes an obstacle for the infrastructure development of the school. 


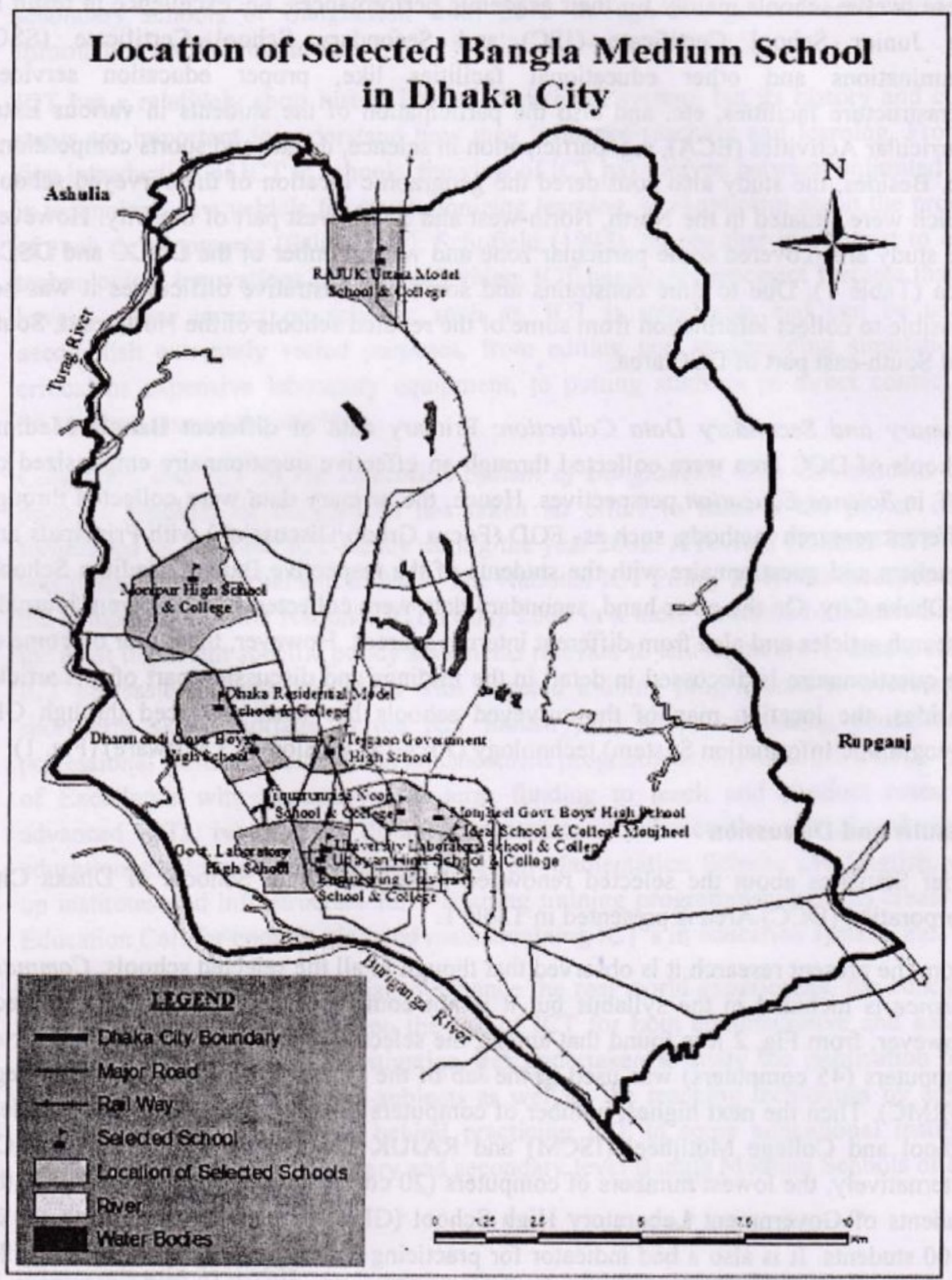

Fig. 1. Location Map of Selected Renowned Bangla Medium Schools in Dhaka City.

[" The map is prepared by the authors from both the integration of field data and GIS technology.] 
Table 1. Statistics about the Selected Bangla Medium Schools.

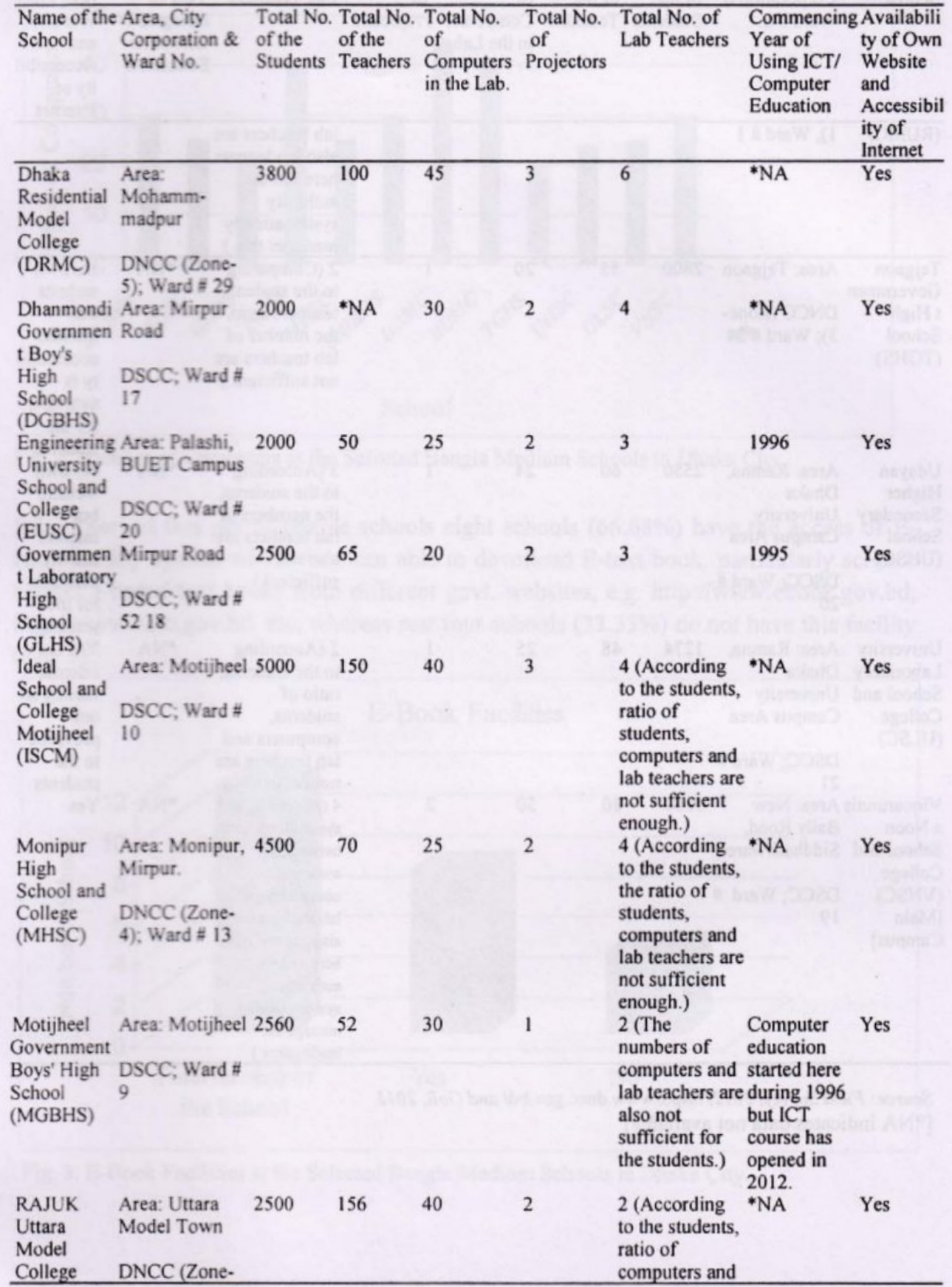


Contd.

\begin{tabular}{|c|c|c|c|c|c|c|c|c|}
\hline \multicolumn{2}{|c|}{ Name of the Area, City } & \multirow{2}{*}{$\begin{array}{l}\text { Total No. } \\
\text { of the } \\
\text { Students }\end{array}$} & \multirow{2}{*}{$\begin{array}{l}\text { Total No. } \\
\text { of the } \\
\text { Teachers }\end{array}$} & \multirow[b]{2}{*}{$\begin{array}{l}\text { Total No. } \\
\text { of } \\
\text { Computers } \\
\text { in the Lab. }\end{array}$} & \multirow{2}{*}{$\begin{array}{l}\text { Total No. } \\
\text { of } \\
\text { Projectors }\end{array}$} & \multirow{2}{*}{$\begin{array}{l}\text { Total No. of } \\
\text { Lab Teachers }\end{array}$} & \multicolumn{2}{|c|}{ Commencing Availabili } \\
\hline 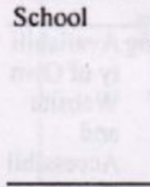 & $\begin{array}{l}\text { Corporation \& } \\
\text { Ward No. }\end{array}$ & & & & & & $\begin{array}{l}\text { Year of } \\
\text { Using ICT/ } \\
\text { Computer } \\
\text { Education }\end{array}$ & $\begin{array}{l}\text { ty of Own } \\
\text { Website } \\
\text { and } \\
\text { Accessibil } \\
\text { ity of } \\
\text { Internet }\end{array}$ \\
\hline$\overline{\text { (RUMC) }}$ & 1), Ward \# I & & & & & $\begin{array}{l}\text { lab teachers are } \\
\text { also inadequate } \\
\text { here but the } \\
\text { authority } \\
\text { systematically } \\
\text { manages this.) }\end{array}$ & & \\
\hline $\begin{array}{l}\text { Tejgaon } \\
\text { Governmen } \\
\text { t High } \\
\text { School } \\
\text { (TGHS) }\end{array}$ & $\begin{array}{l}\text { Area: Tejgaon } \\
\text { DNCC (Zone- } \\
\text { 3); Ward } \# 24\end{array}$ & 2400 & 55 & 20 & 1 & $\begin{array}{l}2 \text { (Comparing } \\
\text { to the students- } \\
\text { teachers ratio, } \\
\text { the number of } \\
\text { lab teachers are } \\
\text { not sufficient.) }\end{array}$ & *NA & $\begin{array}{l}\text { No own } \\
\text { website } \\
\text { but } \\
\text { internet } \\
\text { accessibili } \\
\text { ty is } \\
\text { available } \\
\text { for the } \\
\text { students. }\end{array}$ \\
\hline $\begin{array}{l}\text { Udayan } \\
\text { Higher } \\
\text { Secondary } \\
\text { School } \\
\text { (UHSC) }\end{array}$ & $\begin{array}{l}\text { Area: Ramna, } \\
\text { Dhaka } \\
\text { University } \\
\text { Campus Area } \\
\text { DSCC; Ward \# } \\
20\end{array}$ & 2550 & 60 & 24 & 1 & $\begin{array}{l}3 \text { (According } \\
\text { to the students, } \\
\text { the numbers of } \\
\text { lab teachers are } \\
\text { also not } \\
\text { sufficient.) }\end{array}$ & *NA & $\begin{array}{l}\text { No own } \\
\text { website } \\
\text { but } \\
\text { internet } \\
\text { facility is } \\
\text { available } \\
\text { for the } \\
\text { students. }\end{array}$ \\
\hline $\begin{array}{l}\text { University } \\
\text { Laboratory } \\
\text { School and } \\
\text { College } \\
\text { (ULSC) }\end{array}$ & $\begin{array}{l}\text { Area: Ramna, } \\
\text { Dhaka } \\
\text { University } \\
\text { Campus Area } \\
\text { DSCC; Ward \# } \\
21\end{array}$ & 1274 & 48 & 25 & 1 & $\begin{array}{l}2 \text { (According } \\
\text { to the students, } \\
\text { ratio of } \\
\text { students, } \\
\text { computers and } \\
\text { lab teachers are } \\
\text { not enough.) }\end{array}$ & *NA & $\begin{array}{l}\text { Yes but } \\
\text { internet } \\
\text { facility is } \\
\text { not } \\
\text { provided } \\
\text { to the } \\
\text { students }\end{array}$ \\
\hline $\begin{array}{l}\text { Viquarunnis } \\
\text { a Noon } \\
\text { School and } \\
\text { College } \\
\text { (VNSC) } \\
\text { [Main } \\
\text { Campus] }\end{array}$ & $\begin{array}{l}\text { Area: New } \\
\text { Baily Road, } \\
\text { Siddheshwaree } \\
\text { DSCC; Ward \# } \\
19\end{array}$ & 5000 & 80 & 30 & 2 & $\begin{array}{l}4 \text { (According to } \\
\text { the students, ratio } \\
\text { between } \\
\text { students- } \\
\text { computers and } \\
\text { lab teachers are } \\
\text { also not enough } \\
\text { here, but the } \\
\text { authority } \\
\text { systematically } \\
\text { manage the } \\
\text { inadequacy.) }\end{array}$ & "NA & Yes \\
\hline
\end{tabular}

Source: Field Survey, 2012, http://www.dncc.gov.bd/ and GoB, 2011. [*NA indicates data not available] 


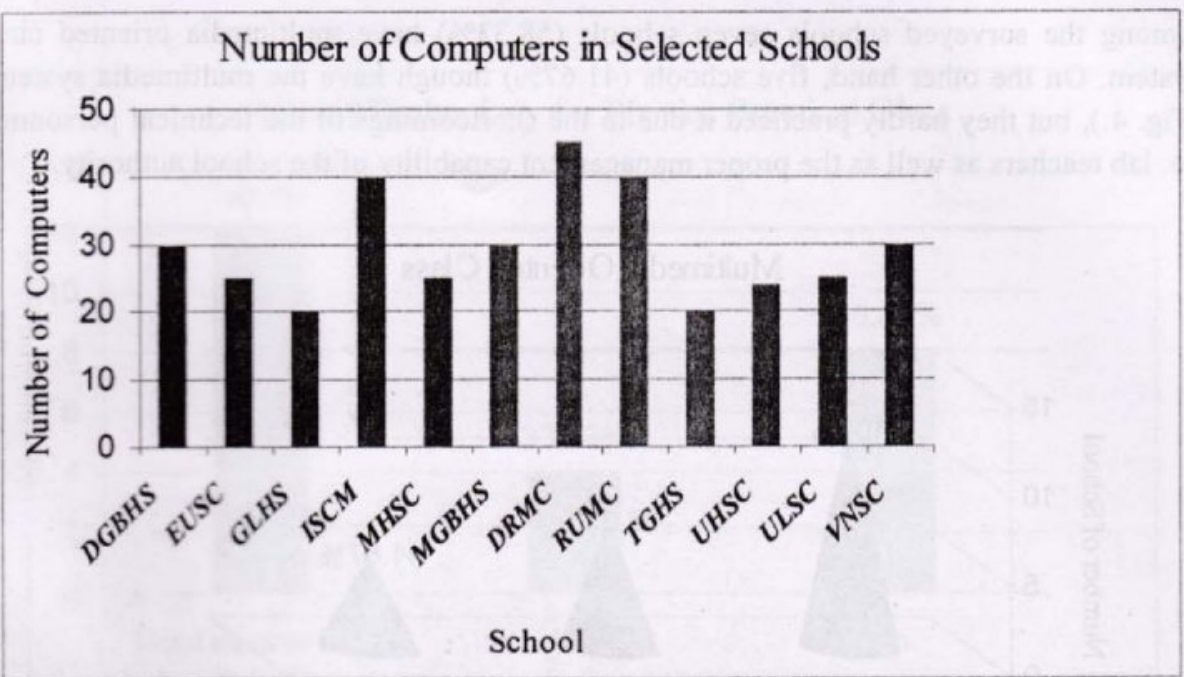

Fig. 2. Number of Computers at the Selected Bangla Medium Schools in Dhaka City.

It is observed that out of twelve schools eight schools $(66.68 \%)$ have the access of Ebook facility system where they can able to download E-text book, particularly science subject's based text books from different govt. websites, e.g. http://www.ebook.gov.bd, http://www.nctb.gov.bd, etc; whereas rest four schools (33.33\%) do not have this facility (Fig. 3).

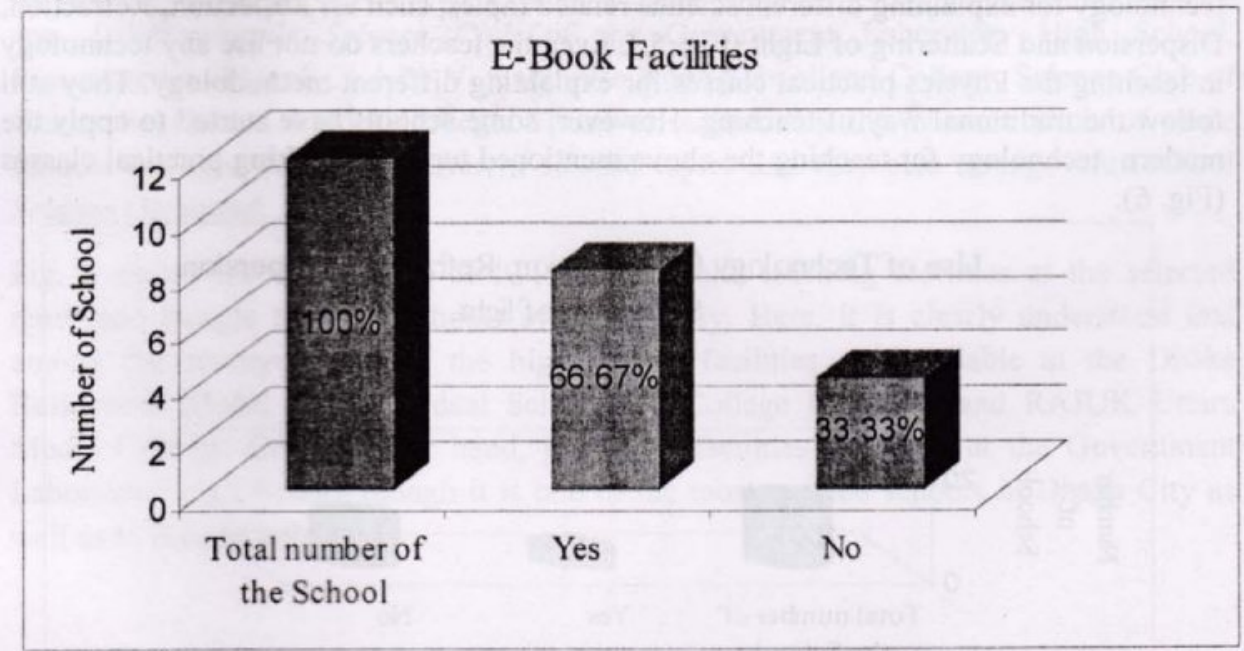

Fig. 3. E-Book Facilities at the Selected Bangla Medium Schools in Dhaka City. 
Among the surveyed schools seven schools $(58.33 \%)$ have multimedia oriented class system. On the other hand, five schools (41.67\%) though have the multimedia systems (Fig. 4.), but they hardly practiced it due to the shortcomings of the technical personnel, i.e. lab teachers as well as the proper management capability of the school authority.

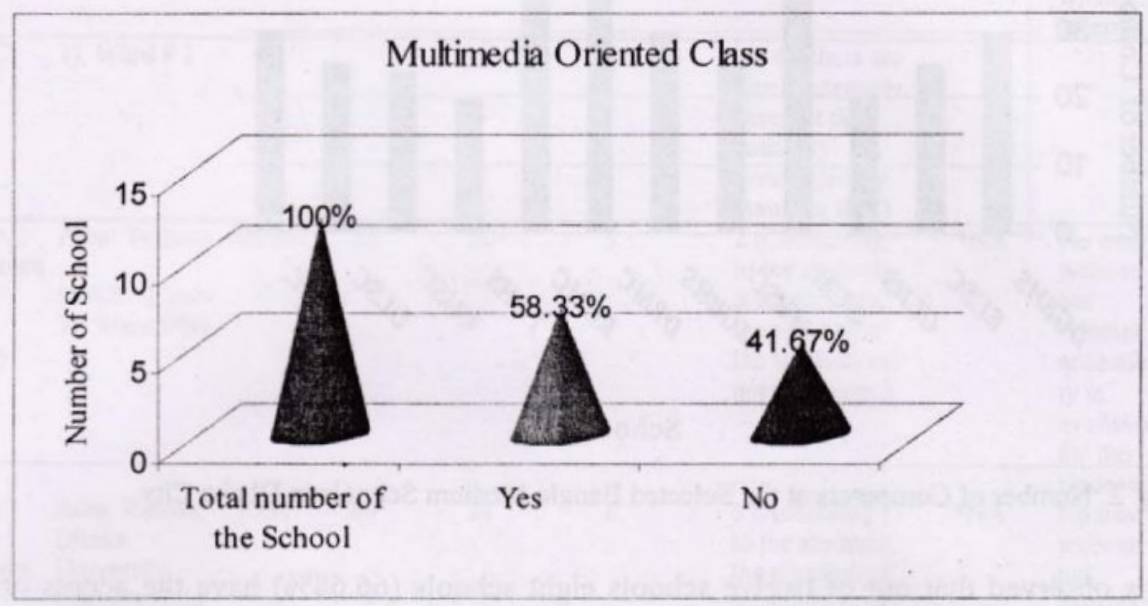

Fig. 4. Multimedia Oriented Class System at the Selected Bangla Medium Schools in Dhaka City.

Most of the selected renowned schools (nine schools, $75 \%$ ) of Dhaka City still do not use technology for explaining different science related topics, such as, Reflection, Refraction, Dispersion and Scattering of Light (Fig. 5.). Even the teachers do not use any technology in teaching the Physics practical classes for explaining different methodology. They still follow the traditional way of teaching. However, some schools have started to apply the modern technology for teaching the above mentioned topics and taking practical classes (Fig. 6).

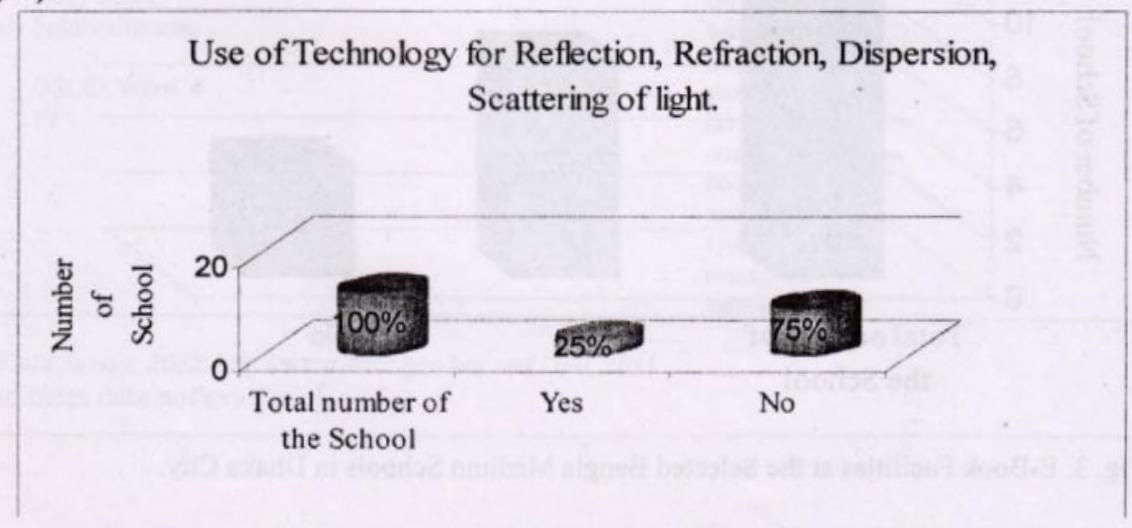

Fig. 5. Use of Technology to teach Reflection, Refraction, Dispersion and Scattering of Light. 


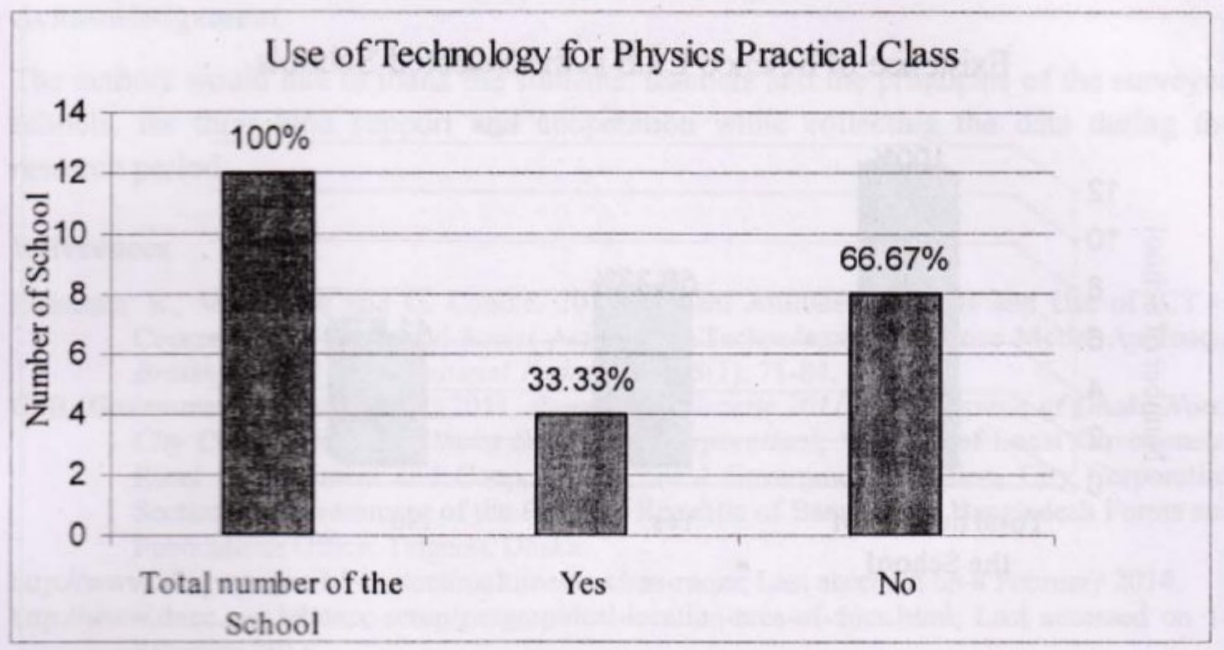

Fig. 6. Use of Technology for Physics Practical Class.

Most of the selected reputed schools (seven schools) of Dhaka City have their own Science Club (Fig. 7). The member of the respective clubs regularly participated in different science fair and involved in doing science project. Besides, they applied technology while doing science project. Among the science clubs the most notable ones are- Laboratorian's Science Club of the Government Laboratory High School, Viquarunnisa Science Club by Viquarunnisa Noon School and College, Science Club of Dhaka Residential Model College. However, sometimes the Science Club of these schools arranges debate on different science topics and they also arrange intra-school Science Olympiad.

Fig. 8 shows the comparison of ICT facilities and teaching facilities at the selected renowned Bangla Medium schools of Dhaka City. Here, it is clearly understood that among the surveyed schools the highest ICT facilities are available at the Dhaka Residential Model College, Ideal School and College Motijheel and RAJUK Uttara Model College. On the other hand, poor ICT facilities observed at the Government Laboratory High School though it is one of the most reputed schools in Dhaka City as well as in Bangladesh. 


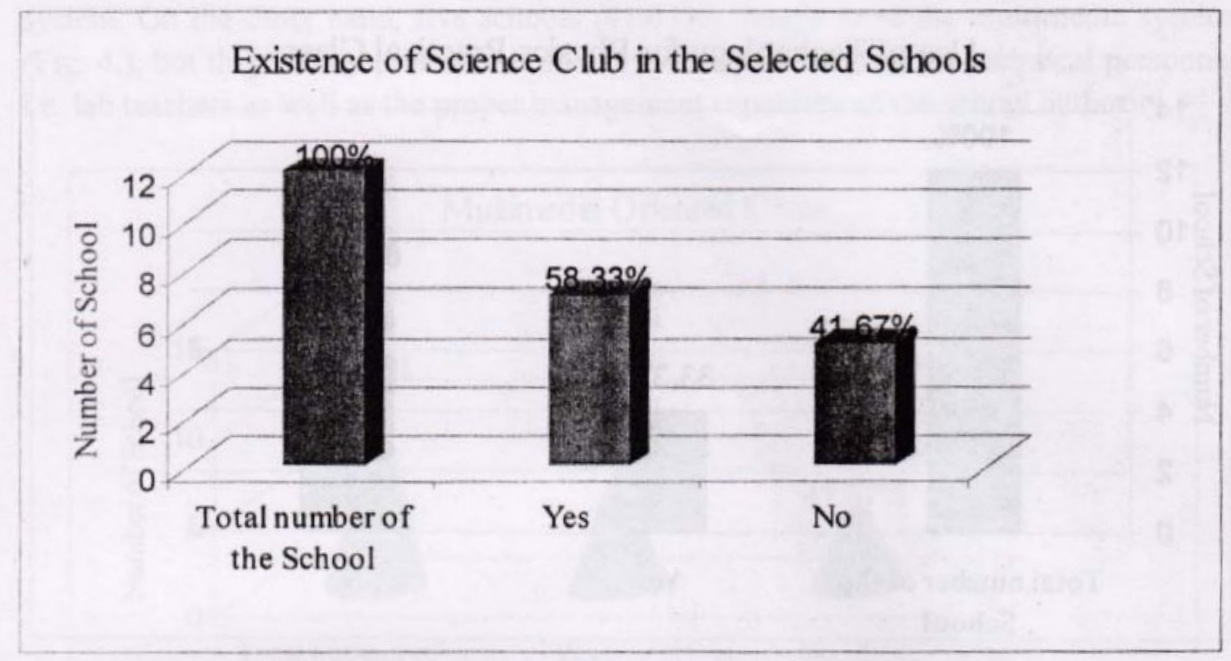

Fig. 7. Existence of Science Club in the Selected Schools.

ICT can help the knowledge and information to become more democratic, more socially owned, more easily accessible, and more transparent. The importance of digital Bangladesh in true sense has significant importance to keep pace with this technologically advanced society and the world. So, nowadays, in every steps of life, ICT plays an important role as a development indicator. Through the proper application of ICT in Science Education at the school level, Bangladesh will be able to compete with the other nations of the world in the forefront digital decades. To enhance the quality of the education system and to compete with the digital world it is vital to set up ICT facilities for learning Science Education with proper monitoring and management system by the respective authority.

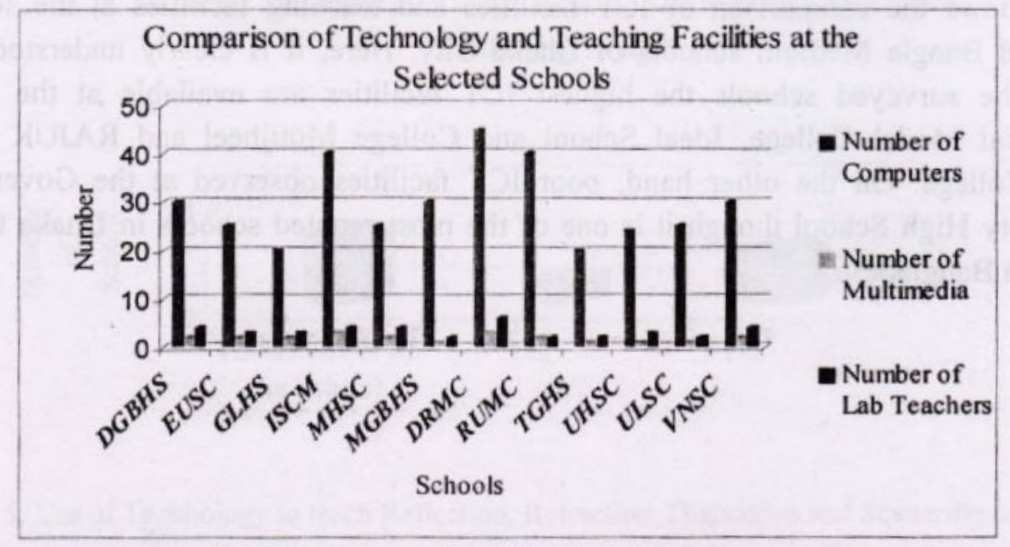

Fig. 8. Comparison between Technology and Teaching Facilities at the Selected Schools. 


\section{Acknowledgement}

The authors would like to thank the students, teachers and the principals of the surveyed schools, for their kind support and cooperation while collecting the data during the research period.

\section{References}

Edmunds, R., M. Thorpe and G. Conole. 2012. Student Attitudes Towards and Use of ICT in Course Study, Work and Social Activity: A Technology Acceptance Model Approach. British Journal of Educational Technology. 43(1): 71-84.

GoB (Government of Bangladesh) 2011. Bangladesh Gazette 2011 (Area Gazette of Dhaka North City Corporation and Dhaka South City Corporation), Ministry of Local Government, Rural Development and Cooperatives, Local Government Division, City Corporation Section- 1, Government of the People's Republic of Bangladesh, Bangladesh Forms and Publications Office, Tejgaon, Dhaka.

http://www.a2i.pmo.gov.bd/content/multimedia-class-room; Last accessed on 8 February 2014.

http://www.dncc.gov.bd/dncc-setup/geographical-location-area-of-dncc.html; Last accessed on 14 February 2014

http://www.en.wikipedia.org/wiki/Science_education; Last accessed on 12 February 2014.

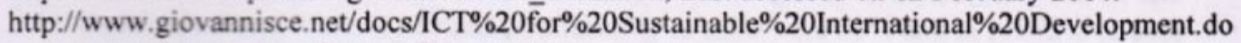
c; Last accessed on 12 February 2014.

http://www.moedu.gov.bd/index.php?option=com_content\&task=view\&id=252\&Itemid=426; Last accessed on 8 February 2014.

Schofield, J. W. 1995. Computers and Classroom Culture. Cambridge University Press. London. pp. 283.

Săljo, R. 1999. Learning as the Use of Tools: A Socio-cultural Perspective on the Humantechnology Link. In: Learning with Computers: Analysing Productive Interaction (Eds. K. Littleton \& P. Light). London, Routledge. pp. 144-161. 